\title{
I Infection and GVHD
}

\author{
Hans-Jochem Kolb ${ }^{1}$, Daniela Weber ${ }^{2}$, Belinda Pinto Simoes ${ }^{3}$, Ernst Holler $^{2}$ \\ ${ }^{1}$ Kolb Consulting UG, München, Germany \\ ${ }^{2}$ Department of Hematology and Oncology, Internal Medicine III, University Medical Center, Regensburg, Germany \\ ${ }^{3}$ Ribeirao Preto School of Medicine, Sao Paulo University, Brazil
}

Prof. Dr. Hans-Jochem Kolb, Kolb Consulting UG,

Riesstrasse 66, 80993, München, Germany
Phone/fax: 0049/(0)89/3089839

E-Mail: h-j-kolb@web.de

\section{Summary}

The role of infections in allogeneic stem cell transplantation and graft-versus-host disease has gained a renewed interest because of several developments in recent years. Variable degrees of immune deficiency exist as a consequence of immune suppression until the immune system of donor origin is established; graft-versus-host disease (GVHD) and immunosuppressive treatment for prophylaxis and therapy may delay the restoration. These conditions favor infections with various microorganisms. Several improvements in prophylaxis and treatment of infections as well as reduced intensity of the conditioning regimens and improved prophylaxis of GVHD have decreased toxicity of the treatment and transplant-related deaths.

Improved antibiotics, antiviral and antifungal treatment have contributed to the greater success. However, infections with and without GVHD remain a major obstacle of allogeneic stem cell transplantation and immunotherapy. New diagnostic tools for the study of cytokines released during conditioning, the composition and alteration of the gut microbiome after transplantation and the innate immunity of the gut mucosa have given new insights into the pathophysiology of GVHD. The gut is a primary organ of T cell activation in acute GVHD; the incidence of GVHD is associated with a lower gut microbial diversity.

The composition of intestinal microbiota seems to play an important role for the pathophysiology of intestinal GvHD. Commensal bacteria, particularly Clostridiales, like Blautia, have been shown to be associated with less GvHD. The mechanism by which anaerobic bacteria suppress GVHD is still unknown, most likely due to secretion of protective metabolites like short chain fatty acids or indole and its derivatives, thus exerting antiiflammatory effects and contribute to epithelial integrity and immunological homeostasis. Modulation of intestinal microbiota composition may influence the occurrence and severity of gut GvHD.
The form of gut decontamination has also an important impact on GVHD. E.g., rifaximin is a broad-spectrum antibiotic with negligible gastrointestinal resorption that spares anaerobic bacteria and improves indoxyl sulfate production. Rifaximin preserves high microbiome diversity upon gut decontamination, as compared to ciprofloxacin and metronidazole being associated with less severe GI GvHD and improved survival.

Even kind and timely use of systemic broad-spectrum antibiotics for therapy of neutropenic infections seems to impact gut GvHD. E.g., avoidance of imipenem/cilastatin and piperacillin/tazobactam seems to improve survival by decreasing GVHD rates, probably, due to growth of Akkermannsia muciniphilia with mucus-degrading capabilities, thus, probably, promoting intestinal inflammation and GvHD. Aztreonam and cefipime, both antibiotics with anaerobic sparing effects, may be preferable. Use of antibiotics before the day of transplantation may contribute to severe intestinal dysbiosis and poor outcome of patients after ASCT.

The presence of certain strains of anaerobic bacteriae is associated with lower risks of GVHD and relapse of leukemia. Recent studies have shown that gut colonization with some strains of Blautia is associated with lesser risk of GVHD, and strains of Limus (Eubacteriaceae) is associated with a decreased relapse rate. This antileukemic mechanism is not well understood. A common finding is the production of short chain fatty acids. Hence, the question of total or selective gut decontamination is discussed controversially. Improved survival was described with the decontamination with rifaximin that is associated with surviving anaerobes and an increased production of indolsulfoxide. Treatment of GVHD of the gut has been attempted with the transfer of stool from a healthy person with some success. This may not only be the beneficial impact of bacteriae, but the composition of bacteriae with phages and other microorganisms.

A recent study of the viriome found the presence of picobrna virus associated with GVHD. 
The gastrointestinal mucosa is an important part of the immune system and there is a delicate equilibrium between the flora itself and the immune surveillance by the host's immune system. There is a good evidence that the mucosal immune system plays a pivotal role in the development of the patient's immunity against food antigens and microbial antigens thereby distinguishing between reaction and tolerance.

Viral infections are known to pave the way for subsequent fungal and bacterial infections, but complex interactions between the viruses, bacteria, fungi, nematodes and host mucosa may complicate the picture. A still largely unknown but highly important mechanism of transkingdom control may be associated with poorly studied role of phages that may modulate bacterial colonization. These interactions may be complicated by clinically applied antibiotics (absorbable and non-absorbable), antivirals and other drugs.
There are also some encouraging new ways to prevent and to treat GVHD. Moreover, one may select donors according to their immune repertoire and genetic background for T cell activation. Possibly this can be combined with an anti-leukemic efficiency based on anti-microbial activity and HLA class II DP histocompatibility. In general, the immune activation may be important that is induced by the actual microbiome and determined genetically by the donor and the host.

\section{Keywords}

Allogeneic hematopoietic cell transplantation, graft-versus-host disease, infection, prevention, gut microbiota, genetic factors, anti-infectious therapy.

\section{Introduction}

In allogeneic stem cell transplantation there is a variable degree of immune deficiency due to transient hematopoietic insufficiency, graft-versus-host disease (GVHD) and immunosuppressive treatment for prophylaxis and therapy. These conditions favor infections with various microorganisms; they may be transferred from outside or may reside inside of the patient. The latter could be reactivated from a latent state or symbiotic state. They may be enhanced by the destruction of mucosal barriers in gut, skin or respiratory tract. Various provisions have been taken in order to minimize the acute phase complications; reduced intensity conditioning and anti-infectious prophylaxis were most successful. However, GVHD is still the major problem of allogeneic stem cell transplantation; skin, gut and liver are still primary target organs and lung diseases may further complicate the syndrome. In the absence of GVHD immunosuppressive therapy can be discontinued 4-6 months after transplantation; persistent chimerism in the absence of GVHD and sufficient protection against infections indicate transplantation tolerance. On the other hand, tolerance should not be induced against the leukemia, since the immune reaction of the graft against the host's leukemia is an essential part of the therapeutic success of allogeneic stem cell transplantation.

The release of cytokines by the host's immune system during the conditioning phase and prior to transplantation, the so-called "cytokine storm" has a strong impact on the development of acute GVHD and other complications of transplantation [1]. The release of tumor necrosis factor alpha has been described as pathophysiological mechanism of microangiopathy seen after transplantation $[2,3]$. Acute inflammatory reactions and GVHD could be modified by prophylactic treatment with anti-TNF-a antibody [4]. Irradiation and chemotherapy can cause severe damage of the gut epithelium, the break of the mucosal barrier allows infections by crossing bacteria. Oral administration of non-absorbable antibiotics and antifungals has been the traditional form of prophylaxis, because survival of high doses of total body irradiation is increased in decontaminated animals. The role of the gut flora for GVHD was studied by van Bekkum et al. $[5,6]$ : mice received sterile fetal gut implants under the skin prior to irradiation and stem cell transplantation. They found little GVHD in the fetal gut, if the mice were well decontaminated of bacteria, but significant GVHD in conventional mice. The poor acceptance of non-absorbable antibiotics by the patients led to the use of absorbable antibiotics such as fluorchinolon and metronidazole. However, the increasing frequency of resistant bacteria question the use of broad spectrum antibiotic prophylaxis. There is controversy about antibiotic prophylaxis at all with regard to the role of gut flora in the immune homeostasis and its form. Particular emphasis is on the prevention of infections with multi-resistant microorganisms.

\section{Prophylaxis of infections}

At the beginning of allogeneic stem cell transplantation, the experience with reverse isolation of newborn children with severe combined immune deficiency were the basis of research of various forms of isolation and gut decontamination [7-11]. Children with severe combined immune deficiency were delivered by Cesarian section and kept in a sterile environment [7]. The colonization of the gut was a risk in immune deficient children housed in a sterile environment. Therefore these children were occasionally "re-conventionalized" by maternal stool [12] after recovery of some immune functions.

In other patients, prophylactic measures against infections were oriented for the duration of severe neutropenia and the extent of immune deficiency. Most external infections can be prevented by reverse isolation in single bed rooms, washing and disinfection of the hands, and wearing face masks by personal and visitors. HEPA-filtered air protects against airborne infections, in particular mold infections [13]. However, the patients may bring along microorganisms, some of which can be dangerous because of prior hospitalization and 
antibiotic treatment. Antibacterial prophylaxis was originally designed for complete suppression of the intestinal flora. This regimen has been studied with controversial results, significant improvement has been shown in children $[7,8]$ and patients with aplastic anemia [9]. Complete decontamination is rarely possible and partial or selective decontamination has been proposed [14]. This form of decontamination spares anaerobic bacteria in order to induce resistance to the colonization with pathogenic bacteria. However, complete decontamination including metronidazole was found more successful [15]. The oral non-absorbable antibiotics are not very palatable, and most transplant centers have switched to fluorquinolones that are readily absorbed and better accepted by the patients. Recently improved results were described with rifaximin [30]. Rifaximin preserves anaerobic bacteria and depresses colonization with enterococcal species. Some anaerobic bacteria produce short fatty acid and indolsulfoxide that temper proinflammatory changes. Other preventive measures are more preemptive; e.g., the CMV disease can be prevented by preemptive treatment at the time of increasing PCR positivity or antigenemia; non-invasive respirator support is effective in preventing pneumonia.

The predominant infections in the first 2 to 4 weeks after conditioning and transplantation are associated with severe neutropenia, mainly bacterial infections with Gram-negative and Gram-positive bacteria. Severe neutropenia of more than 10 days duration is often complicated by infections with Gram-positive bacteria and fungi. Nosocomial infections with resistant strains create an increasing problem [16]. Moreover, herpes simplex infections can be reactivated by the conditioning treatment including total body irradiation, and prophylactic treatment with acyclovir has been beneficial. The period of marrow aplasia ends with the recovery of reticulocytes, granulocytes and platelets. The following period is characterized by immune recovery and graft-versus-host reactions.

The period after engraftment until 4-6 months after transplantation is characterized by a slowly recovering immune system and various degrees of immune deficiency and dysfunction. The deficiency is severe in patients with GVHD and its treatment with immunosuppressive medication. Viral infections are frequent and may be life-threatening, fungal infections with Aspergillus are a risk for patients with intense immunosuppression. Encapsulated bacteria can create life-threatening situations in patients with poor antibody responses and splenic atrophy. Immune recovery is improved by higher numbers of stem cells transplanted.

EBV-associated lymphoproliferative disease (PTLD) is more frequent in patients given anti-thymocyte globulin [17] and patients with HLA-mismatched donors [18], CMV infections after the treatment with alemtuzumab [19]. Including the anti-CD20 antibody rituximab into the immunosuppressive conditioning may prevent EBV-associated PTLD [20] because of ablation of B-cells. Anti-viral prophylaxis is commonly given for 4 months after transplantation and the patient should be controlled after discontinuation of anti-viral therapy, because of an increased risk of viral infections after the discontinuation. Antibiotic prophylaxis should be given in patients with acute or chronic GVHD on immunosuppressive therapy, or patients with asplenia syndrome.
This can be diagnosed by sonography and the finding of Jolly bodies in red blood cells.

Vaccination against pneumococci, Hemophilus influenzae, meningococci should be given at 6 months after transplantation, preferably as protein-conjugated vaccines [21]. Prior to vaccination, immunosuppressive treatment should be discontinued, and GVHD should be absent; the CD4 count should be more than $200 / \mu \mathrm{l}$ and CD19>20/ $\mu$ l. Live attenuated vaccines should not be given earlier than 2 years after transplantation. Special attention for flu' vaccination is required in the influenza season; sexually active persons may require vaccination against human papillomavirus. Presently there is no clear evidence that vaccination has a negative impact on GVHD.

There is a significant reduction in treatment-related mortality; several factors may be responsible. Major progress came from treatment with better antibiotics, anti-virals and anti-fungals, but also from reducing the intensity of conditioning treatments [22]. In general, acute GVHD is less severe and occurs later in patients conditioned less intensively. Less intensive conditioning liberates less cytokines and particularly TNF- $\alpha$. Treatment with TNF- $\alpha$ antibody during conditioning treatment [4] tempers the cytokine storm. Shorter period of fever was observed, along with less acute GVHD which occurred at later terms. Moreover, a reduced-intensity conditioning is also associated with diminished damage of epithelial barrier and, thus, prevents translocation of bacteria and their pathogen associated molecular patterns to the gut lymphoid tissues being a pre-requisite for immune activation.

Apart from conditioning and its regimen, preventive measures of infections are extremely important for two reasons: absence of infectious risks allows immunosuppressive treatment of GVHD without overwhelming infections which may incite GVHD by several mechanisms including stimulation of innate immune mechanism, up-regulation of class II HLA, cross-reactivity and epitope spreading [29]. Today we know that innate immunity plays a major role in the induction of GVHD [31-33].

There are several findings pointing to the gut as primary organ of T cell activation in acute GVHD; mice without Peyers patches do not develop acute GVHD [25], blockade of the CXCR5 chemokine receptor with maraviroc reduces acute GVHD in patients $[26,27]$, patients with mutations in intracellular defense to bacteria (NOD/CARD2) develop more GVHD [28]. Therefore, the gut plays a decisive role in the initiation of GVHD and the patients' fate with GVHD. Interestingly, gut GVHD does not correlate with graft-versus-leukemia activity.

The impact of the intensity of conditioning varies between diseases and stages of the disease. In many instances control of leukemia was not achieved by the intensity of conditioning, but an immune reaction of donor lymphocytes against the leukemia $[23,24]$.

\section{The gut microbiome and GVHD}

Early experiments of R. Truitt and colleagues had shown that mice could be cured of AKR leukemia and SJL lympho- 
ma by allogeneic transplantation; they survived, if their gut was germ-free $[34,35]$. Several studies have shown superior survival with successful gut decontamination [8] [10], but others failed to improve survival after allogeneic stem cell transplantation for leukemia [11]. Prevention of infection with potentially pathogenetic bacteria translocated from the intestinal flora is one aspect, initiation of immune responses and building up of an immune repertoire is the other aspect. The gastrointestinal mucosa is an important part of the immune system, and there is a delicate equilibrium between the flora itself and the immune surveillance by the host's immune system. Blood group isoagglutinins are produced after colonization with E. Coli and even transient colonization of the mother's gut during pregnancy improves the immune reactivity in the cubs [36]. There are genetic and dietary conditions that determine the composition of the gut flora [37]. In the meantime many gut associated immune mechanisms have been clarified, not only microbiota, but also food antigens drive the development of the immune system to immunity and tolerance [38]. Tolerance against solid food is mediated by regulatory $\mathrm{T}$ cells induced by $\mathrm{CD} 103+$ and $\mathrm{CD} 11 \mathrm{c}+$ dendritic cells in the gut mucosa; regulatory $\mathrm{T}$ cells induced by microbial antigens persist longer than those evoked by food antigens. The role of adaptive immune responses and the antigens involved is not well defined. Any way, the gut microbiome may represent an important part of the immune repertoire of each individual [39].

Most investigations of intestinal microbiology were directed to mechanisms of innate immunity that may or may not be important to alloimmune responses. Intracellular microbial pattern recognition receptors (NOD/CARD2) [40] have a role in GVHD and other complications of allogeneic transplantation; mutations in the donor's and the host's cells increase the risk of complications. Interestingly, this is not the case in patients decontaminated with the traditional non-absorbable antibiotics (unpublished). Paneth cells produce antimicrobial peptides like Reg IIIa; increased serum levels are early indicators of gut GVHD [41]. Similarly, fecal calprotectin is produced by activated macrophages, it has been described as biomarker for gut GVHD and refractoriness to steroid therapy [42]. The destruction of the mucosal barrier during conditioning and GVH-reactions against the gut epithelium enhances translocation of bacteria from the gut lumen to the blood flow $[31,43]$, diarrhea followed by septicemia and pneumonia has a dismal prognosis.

Surveillance cultures of the microbial flora of the intestine were performed since the start of stem cell transplantation in the 70s [7], but the success was variable and GVHD resulting in colonization with single strains resistant to the treatment was observed. Recently, diagnostic tools have improved by testing of bacterial 16S RNA genes. A great variety of bacteria can be detected, the greater the diversity the lesser GVHD [44]. However, not only the host's immune system determines the composition of microbiota, but the flora itself is controlling its composition creating colonization resistance. B.thetaiotamicron, B.thuringiensis, Bifidobacteria spp play a role in controlling the colonization of the gut [45].

The composition of intestinal microbiota seems to play an important role for the pathophysiology of intestinal GvHD.
Commensal bacteria, particularly Clostridiales, like Blautia, have been shown to be associated with less GvHD [46]. These results were confirmed as low levels of 3-indoxylsuflate, a tryptophan metabolite of Clostridiales, early after transplantation have been observed to correlate with poor outcome and increased GvHD-related TRM [47]. Modulation of intestinal microbiota composition may influence the occurrence and severity of gut GvHD as shown in experimental murine models fed with Lactobacillae [48] or butyrate-producing Clostridiales.

The mechanism by which anaerobic bacteria suppress GVHD is still unknown, most likely it is the secretion of protective metabolites like short chain fatty acids or indole and its derivatives. They exert a lot of anti-inflammatory effects and contribute to the maintenance of epithelial integrity and immunological homeostasis. Recently a role for indoxylsulfate was defined in patients with GVHD. Indoxyl sulfate is produced by anaerobic bacteria and protects the mucosal barrier.

The form of gut decontamination has also an important impact on GVHD; rifaximin is a broad-spectrum antibiotic with negligible gastrointestinal resorption that spares anaerobic bacteria and improves indoxyl sulfate production [30]. As compared to ciprofloxacin and metronidazole for gut decontamination rifaximin preserves high microbiome diversity and was associated with less severe GI GvHD and improved survival. The beneficial effect of rifaximin was independent of poor prognostic factors as the mutated genotype of NOD CARD2 and treatment with systemic antibiotics prior to transplantation [48].

Even the kind and timepoint of use of systemic broad-spectrum antibiotics for therapy of neutropenic infections seem to impact GI GvHD. The avoidance of imipenem/cilastatin and piperacillin/tazobactam during the neutropenic period improved survival by decreasing GVHD [49]. These antibiotics favored the growth of Akkermannsia muciniphilia, a bacterium with mucus degrading capabilities, that may contribute to the development of intestinal inflammation and GvHD. Aztreonam and cefipime, both antibiotics with anaerobic sparing effects may be preferable under this condition. However, also the time of starting therapeutic antibiotics can influence gastrointestinal GvHD as antibiotic use before the day of transplantation contributed to severe intestinal dysbiosis and poor outcome of patients after ASCT.

However, a more general effect of immunoregulation by microbiota can be expected. A large variety of immunoregulatory cells in the gut depends on the presence of short chain fatty acids (regulatory T cells), on arylhydorcarbon acid ligands such as indoles (ILCs type 3 ) or on bacterial products like vitamins (invaraint NKT cells). Microbiote dysruption thus interferes with a well tuned balance of immunregulatoy cells which is essential for tissue tolerance.

A most encouraging observation was the finding that colonization with certain groups of bacteria (Eubacteriaceae) like Enterobacterium limosum is associated with a decreased relapse rate [50]. The antileukemic mechanism is not well understood. Possibly inhibition of inflammatory changes in the gut improve the control of the disease. Stimulation of CD8 
$\mathrm{T}$ cells via toll-like receptor binding may be another cause [51] as well as the inhibition of checkpoint inhibitors CTLA4 [52] and PD-1L [53] that are influenced by the microbiome of the gut.

Therefore, the gut microbiome has an as yet poorly defined impact on the structure of the immune system; it certainly contributes to the development of an immune repertoire, the prevention of autoimmune disease and the situation of allogeneic stem cell transplantation, foreign immune cells not only encounter histocompatibility differences, but also a new microbial environment and innate defense mechanisms of the gut.

\section{Viral Infection}

Viral infections are a particular challenge for allogeneic $\mathrm{T}$ cells, because they are strictly intracellular; the activation of cellular immune responses require signals of activation on the cell surface. Except for viremia antibodies are not required, viruses can spread from cell to cell. Most problems are from reactivation of persistent or latent viral infections, although primary infections do occur. Immune deficiency is the primary cause for viral reactivation, the immune reaction against cells with latent viral infection may contribute to viral reactivation. This way a vicious circle may ensue with GVHD and CMV exchanging each other.

Prototypes for reactivation are infections with herpesviruses: herpes simplex virus (HSV), herpes zoster virus (HZV), cytomegalovirus (CMV) and Epstein Barr virus (EBV), but also other viruses may produce disease after activation, like $\mathrm{BK}$ and JC virus, adeno-virus, hepatitis viruses, papilloma virus and others. Clinical herpes simplex infections have been greatly reduced by the prophylactic treatment with acyclovir. Unfortunately, acyclovir is not very effective in CMV infections and CMV associated interstitial pneumonitis and colitis have been great clinical problems in allogeneic stem cell transplantation. The introduction of more effective antiviral drugs and better diagnostic has changed the dangers of CMV infections, prophylactic or preemptive treatment with ganciclovir in case of increasing quantitative PCR loads in blood could prevent disease. CMV is often found in biopsies of patients with GVHD [54-56] and inflammatory bowel disease [57]. CMV infection is a serious complication of gut GVHD and contributes to mortality. However, it may also contribute to GVHD as it has been described for CD4 T cells that induce GVHD via inflammatory signals increasing the expression of HLA class II on non-hematopoietic cells [58]. On the other hand, CD4 T cells are necessary in order to control CMV disease [59] [60, 61]. More recently cross-reactive peptides have been described between CMV and minor histocompatibility antigens [54]. In patients with AML, a successful control of CMV infection during the first 100 days after transplantation correlated with a decreased risk of relapse [62].

Reactivation of HHV-6 is seen in nearly $50 \%$ of patients with allogeneic transplants, but it is still not clear whether HHV-6 has a pathogenic role in GVHD. We observed HHV-6 in skin biopsies taken for GVHD that did not respond to steroids [unpublished]. HHV6 genes are integrated in the human genome in $1-3 \%$ of patients and donors; in these patients
GVHD may be more frequent [63]. In retrospective reviews HHV-6 was associated with bone marrow failure, skin rash, enteritis and CNS disease [64], but the associations were not strong.

Therefore, the interaction of viral infection and GVHD may be mutual: immune deficiency related to GVHD and its treatment favors reactivation of viral infections, and they may provide the inflammatory environment to stimulate GVHD. The inflammatory environment is a potent condition for reactivation of latent virus [65].

Immunotherapy of viral infection with specific cytotoxic $\mathrm{T}$ cells has been successful in patients with post-transplant lymphoproliferative disease (PTLD) with reactivation of EBV. An important risk factor of PTLD is the treatment with antithymocyte globulin and anti-T-cell antibodies. Again, it is not known why some anti-T-cell antibodies have a high risk of PTLD and others a rather low risk. Severe adenovirus infections can be associated with GVHD of the gastrointestinal tract, reactivation and new infections may occur, risk factors are GVHD and immune suppression [66]. In some cases with severe diarrhea rota virus is found together with adenovirus.

Hepatitis virus infection presents an important differential diagnosis of GVHD of the liver. Hepatitis B virus may be reactivated in patients with a history of hepatitis as evident by anti-core antibodies, even in the presence of anti-surface antibodies. An antiviral prophylaxis is indicated in patients with long-term immune suppression, antiviral therapy is indicated during transplantation and until a year after discontinuation of immune suppression [67]. The presence of hepatitis $\mathrm{C}$ is not considered as a contraindication against allogeneic transplantation, but it should be treated in order to prevent cirrhosis and hepatic carcinoma [68]. In a matched control study, the outcome for patients with hepatitis $\mathrm{C}$ virus infection was worse than in the control group [69]. As a rule, patients are not tested for hepatitis E, but recently infections with hepatitis E have been described [70]. Again, elevated transaminases may be considered as an evidence for liver GVHD, but hepatitis E disease may also be present. This infection is rarely associated with clinical disease, but in immunosuppressed patients it may cause mild hepatitis. Treatment with ribavirin and interferon-a can be used for the control of the disease (unpublished observation).

The role of viral infections in GVHD may be variable, reactivation of hepatitis virus is enhanced by immune suppression and the clinical manifestation of hepatitis occurs with the recovering immunity. Therefore, the use of cytotoxic $\mathrm{T}$ cells against hepatitis virus may be harmful. In contrast the use of specific cytotoxic T cells against EBV may be life-saving in cases of EBV reactivation and post-transplant lymphoproliferative disease (PTLD) [71, 72].

Adenovirus infections are more frequent in pediatric patients; prolonged viremia can be seen, reactivation may occur from tonsils, nasopharyngeal and gastrointestinal mucosa. This can be observed prior to the development of GVHD, possibly by inducing an inflammatory response. The use of specific Th1 helper cells against adenovirus was successful in controlling adenovirus disease in 15 of 30 patients; increased 
GVHD was not observed, but 15 patients died with and without a response to T cells $[66,73]$. Adeno-virus specific $\mathrm{T}$ cells were collected by the interferon-capture technique and resulted in a $70 \%$ specific $T$ cells. Non-selected donor lymphocytes were also effective, but carried the risk of GVHD [74] [own unpublished observation]. Adenovirus induces an inflammatory response that may precipitate GVHD [75].

These observations strongly support the treatment of opportunistic and reactivated viral infections while treating GVHD with immune suppression.

A recent study on the gut virome on 44 patients has described a viral "bloom" of DNA viruses following stem cell transplantation that increased in patients with GVHD with a decrease in phage richness [76]. However, only picobirnaviruses were predictive of severe enteric GVHD. These were detected in $40,9 \%$ of patients and correlated with fecal levels of calprotectin and a-1 antitrypsin.

\section{Transkingdom control}

The microbiome has already achieved much attention by transplanters and the medical community; the virome is gaining increasing attention [76]. However, the microbial environment consists also of interactions of various elements. Viral infections may provide the soil for fungal and bacterial infections, but interactions of virus, bacteria, fungi, nematodes and host mucosa may complicate the picture. Norovirus, retrovirus, rotavirus, astrovirus, picornavirus, adenovirus and herpesvirus have intimate regulatory relationship with bacterial microbiota, their phages, helminthes and fungi [77]. Norovirus have ligands to human blood group antigens including secretory antigens and mucus, but also for certain bacteria [78]. In cases of transkingdom activity, norovirus may induce severe intestinal GVHD presumably involving carbohydrate antigens and antibodies (personal observation).

A still largely unknown but highly important mechanism of transkingdom interactions may be the control of microbiome by viral phages. The most recent studies on succesful treatments with fecal microbiota transfer suggest that co-transplanted phages may exert strongest effects upon the microbiome [79].

Part of the transkingdom mechanism is certainly the host's reaction against microorganisms that is genetically predisposed and activated by otherwise harmless microorganisms. More information is available on individual genetic background and activation of Th1,2,17 cells that may determine autoimmune activity in the gut [80]. This genetically determined activation of T cells may be equally important in allogeneic transplantation.

\section{Conclusions}

Major progress has been achieved by the selection of the best donors with histocompatibility testing, prevention of viral, bacterial and fungal infections with improved antibiotics, antiviral and antifungal treatment as well as less intense conditioning regimens [81]. GVHD is still the major problem of allogeneic stem cell transplantation. There are several encouraging new ways to prevent and to treat GVHD including modification of the gut microbiome $[30,49,82]$; it is now time to select donors according to their immune repertoire and their genetic background for T cell activation. Possibly this can be combined with an anti-leukemic effect based on anti-microbial activity $[50,62]$ and HLA class II DP histocompatibility [83]. The immune repertoire may be primed by prior infections as they may be primed by prior transfusions and pregnancies, but activation may be decisive that is induced by the actual microbiome and determined genetically by the donor and the host.

\section{References}

1. Ferrara JL, Cooke KR, Pan L, Krenger W. The immunopathophysiology of acute graft-versus-host-disease. StemCells. 1996;14(5):473-489.

2. Holler E, Kolb HJ, Hiller E, Mraz W, Lehmacher W, Gleixner B, et al. Microangiopathy in patients on cyclosporine prophylaxis who developed acute graft-versus-host disease after HLA-identical bone marrow transplantation. Blood. 1989;73:2018-24.

3. Holler E, Kolb HJ, Moller A, Kempeni J, Liesenfeld S, Pechumer $\mathrm{H}$, et al. Increased serum levels of tumor necrosis factor alpha precede major complications of bone marrow transplantation. Blood. 1990;75:1011-1016.

4. Holler E, Kolb HJ, Mittermüller J, Kaul M, Ledderose G, Duell T, et al. Modulation of acute graft-versus-host disease after allogeneic bone marrow transplantation by tumor necrosis factor (TNF) release in the course of pretransplant conditioning: Role of conditioning regimens and prophylactic application of a monoclonal antibody neutralizing human TNF (MAK 195F). Blood. 1995;86:890-9.

5. van Bekkum DW, Knaan S. Role of bacterial microflora in the development of intestinal lesions from graft-versushost disease. J Natl Cancer Inst. 1977;58:787-792.

6. van Bekkum DW, Roodenburg J, Heidt PJ, van der Waaij D. Mitigation of secondary disease of allogeneic mouse radiation chimeras by modification of the intestinal microflora. J Natl Cancer Inst. 1974;52(2):401-404.

7. Vossen JM, van der Waay D, Dooren LJ. Reverse isolation and decontamination in children with defect of immune capacities and a decrease of colonization resistance. Padiatr Padol. 1972;7(2):120-3.

8. Vossen JM, Guiot HF, Lankester AC, Vossen AC, Bredius RG, Wolterbeek $\mathrm{R}$, et al. Complete suppression of the gut microbiome prevents acute graft-versus-host disease following allogeneic bone marrow transplantation. PloS one. 2014;9(9):e105706.

9. Storb R, Prentice RL, Buckner CD, Clift RA, Appelbaum F, Deeg J, et al. Graft-versus-host disease and survival in patients with aplastic anemia treated by marrow grafts from HLA-identical siblings. Beneficial effect of a protective environment. N Engl J Med. 1983;308(6):302-307.

10. Beelen DW, Elmaagacli A, Muller KD, Hirche H, Schaefer UW. Influence of intestinal bacterial decontamination us- 
ing metronidazole and ciprofloxacin or ciprofloxacin alone on the development of acute graft-versus-host disease after marrow transplantation in patients with hematologic malignancies: final results and long-term follow-up of an open-label prospective randomized trial. Blood. 1999;93(10):32673275 .

11. Routy B, Letendre C, Enot D, Chenard-Poirier M, Mehraj $\mathrm{V}$, Seguin NC, et al. The influence of gut-decontamination prophylactic antibiotics on acute graft-versus-host disease and survival following allogeneic hematopoietic stem cell transplantation. Oncoimmunology. 2017;6(1):e1258506.

12. van der Waaij D, Vossen JM, Altes CK, Hartgrink C. Reconventionalization following antibiotic decontamination in man and animals. Am J Clin Nutr. 1977;30(11):1887-1895.

13. Passweg JR, Rowlings PA, Atkinson KA, Barrett AJ, Gale $\mathrm{RP}$, Gratwohl A, et al. Influence of protective isolation on outcome of allogeneic bone marrow transplantation for leukemia. Bone Marrow Transplant. 1998;21(12):1231-1238.

14. Guiot HF, Furth R. Partial antibiotic decontamination. Br Med J. 1977;1(6064):800-802.

15. Beelen DW, Haralambie E, Brandt H, Linzenmeier G, Muller KD, Quabeck K, et al. Evidence that sustained growth suppression of intestinal anaerobic bacteria reduces the risk of acute graft-versus-host disease after sibling marrow transplantation. Blood. 1992;80(10):2668-2676.

16. Blair JM, Webber MA, Baylay AJ, Ogbolu DO, Piddock LJ. Molecular mechanisms of antibiotic resistance. Nat Rev Microbiol. 2015;13(1):42-51.

17. Hoegh-Petersen M, Goodyear D, Geddes MN, Liu S, Ugarte-Torres A, Liu Y, et al. High incidence of post transplant lymphoproliferative disorder after antithymocyte globulin-based conditioning and ineffective prediction by day 28 EBV-specific T lymphocyte counts. Bone Marrow Transplant. 2011;46(8):1104-1112.

18. Tischer J, Engel N, Fritsch S, Prevalsek D, Hubmann M, Schulz C, et al. Virus infection in HLA-haploidentical hematopoietic stem cell transplantation: incidence in the context of immune recovery in two different transplantation settings. Ann Hematol. 2015;94(10):1677-1688.

19. Chakrabarti S, Mackinnon S, Chopra R, Kottaridis PD, Peggs K, O'Gorman P, et al. High incidence of cytomegalovirus infection after nonmyeloablative stem cell transplantation: potential role of Campath-1H in delaying immune reconstitution. Blood. 2002;99(12):4357-4363.

20. Peccatori J, Forcina A, Clerici D, Crocchiolo R, Vago L, Stanghellini MT, et al. Sirolimus-based graft-versushost disease prophylaxis promotes the in vivo expansion of regulatory $\mathrm{T}$ cells and permits peripheral blood stem cell transplantation from haploidentical donors. Leukemia. 2015;29(2):396-405.

21. Carpenter PA, Englund JA. How I vaccinate blood and marrow transplant recipients. Blood. 2016;127(23):28242832.

22. McSweeney PA, Niederwieser D, Shizuru JA, Sandmaier BM, Molina AJ, Maloney DG, et al. Hematopoietic cell trans- plantation in older patients with hematologic malignancies: replacing high-dose cytotoxic therapy with graft-versus-tumor effects. Blood. 2001;97(11):3390-3400.

23. Kolb HJ, Mittermuller J, Clemm C, Holler E, Ledderose G, Brehm G, et al. Donor leukocyte transfusions for treatment of recurrent chronic myelogenous leukemia in marrow transplant patients. Blood. 1990;76(12):2462-2465.

24. Kolb HJ, Schattenberg A, Goldman JM, Hertenstein B, Jacobsen N, Arcese W, et al. Graft-versus-leukemia effect of donor lymphocyte transfusions in marrow grafted patients 397. Blood. 1995;86(5):2041-2050.

25. Murai M, Yoneyama H, Ezaki T, Suematsu M, Terashima Y, Harada A, et al. Peyer's patch is the essential site in initiating murine acute and lethal graft-versus-host reaction. Nature immunology. 2003;4(2):154-160.

26. Moy RH, Huffman AP, Richman LP, Crisalli L, Wang XK, Hoxie JA, et al. Clinical and immunologic impact of CCR5 blockade in graft-versus-host disease prophylaxis. Blood. 2017;129(7):906-916.

27. Reshef R, Luger SM, Hexner EO, Loren AW, Frey NV, Nasta SD, et al. Blockade of lymphocyte chemotaxis in visceral graft-versus-host disease. N Engl J Med. 2012;367(2):135145.

28. Holler E, Hahn J, Andreesen R, Rogler G, Brenmoehl J, Greinix H, et al. NOD2/CARD15 polymorphisms in allogeneic stem-cell transplantation from unrelated donors: $\mathrm{T}$ depletion matters. J Clin Oncol. 2008;26(2):338-339; author reply 9.

29. Vanderlugt CL, Miller SD. Epitope spreading in immune-mediated diseases: implications for immunotherapy. Nat Rev Immunol. 2002;2(2):85-95.

30. Weber D, Oefner PJ, Dettmer K, Hiergeist A, Koestler J, Gessner A, et al. Rifaximin preserves intestinal microbiota balance in patients undergoing allogeneic stem cell transplantation. Bone Marrow Transplant. 2016;51(8):1087-1092.

31. Ferrara JLM, Deeg HJ. Graft-versus-host disease. N Engl J Med. 1991;324:667-674.

32. Holler E, Kolb HJ, Moller A, Kempeni J, Liesenfeld S, Pechumer $\mathrm{H}$, et al. Increased serum levels of tumor necrosis factor alpha precede major complications of bone marrow transplantation. Blood. 1990;75(4):1011-1016.

33. Holler E, Kolb HJ, Hintermeier-Knabe R, Mittermuller J, Thierfelder S, Kaul M, et al. Role of tumor necrosis factor alpha in acute graft-versus-host disease and complications following allogeneic bone marrow transplantation. Transplant Proc. 1993;25(1 Pt 2):1234-1236.

34. Truitt RL, Pollard M, Srivastava KK. Allogeneic bone marrow chimerism in germfree mice. 3. Therapy of leukemic AKR mice. Proc Soc Exp Biol Med. 1974;146(1):153-158.

35. Pollard M, Truitt RL. Allogeneic bone marrow chimerism in germ-free mice. II. Prevention of reticulum cell sarcomas in SJL-J mice. Proc Soc Exp Biol Med. 1974;145(2):488-492. 
36. Gomez de Aguero M, Ganal-Vonarburg SC, Fuhrer T, Rupp S, Uchimura Y, Li H, et al. The maternal microbiota drives early postnatal innate immune development. Science. 2016;351(6279):1296-1302.

37. Goodrich JK, Davenport ER, Waters JL, Clark AG, Ley RE. Cross-species comparisons of host genetic associations with the microbiome. Science. 2016;352(6285):532-535.

38. Kim KS, Hong SW, Han D, Yi J, Jung J, Yang BG, et al. Dietary antigens limit mucosal immunity by inducing regulatory T cells in the small intestine. Science. 2016;351(6275):858863.

39. Maynard CL, Elson CO, Hatton RD, Weaver CT. Reciprocal interactions of the intestinal microbiota and immune system. Nature. 2012;489(7415):231-241.

40. Holler E, Rogler G, Brenmoehl J, Hahn J, Herfarth $\mathrm{H}$, Greinix $\mathrm{H}$, et al. Prognostic significance of NOD2/ CARD15 variants in HLA-identical sibling hematopoietic stem cell transplantation: effect on long-term outcome is confirmed in 2 independent cohorts and may be modulated by the type of gastrointestinal decontamination. Blood. 2006;107(10):4189-4193.

41. Levine JE, Braun TM, Harris AC, Holler E, Taylor A, Miller $\mathrm{H}$, et al. A prognostic score for acute graft-versus-host disease based on biomarkers: a multicentre study. Lancet Haematol. 2015;2(1):e21-9.

42. O’Meara A, Kapel N, Xhaard A, Sicre de Fontbrune F, Manene D, Dhedin N, et al. Fecal calprotectin and alphal-antitrypsin dynamics in gastrointestinal GvHD. Bone Marrow Transplant. 2015;50(8):1105-1109.

43. Ferrara JL, Levine JE, Reddy P, Holler E. Graft-versushost disease. Lancet. 2009;373(9674):1550-1561.

44. Taur Y, Jenq RR, Perales MA, Littmann ER, Morjaria S, Ling $\mathrm{L}$, et al. The effects of intestinal tract bacterial diversity on mortality following allogeneic hematopoietic stem cell transplantation. Blood. 2014;124(7):1174-1182.

45. Buffie CG, Pamer EG. Microbiota-mediated colonization resistance against intestinal pathogens. Nat Rev Immunol. 2013;13(11):790-801.

46. Jenq RR, Taur Y, Devlin SM, Ponce DM, Goldberg JD, Ahr KF, et al. Intestinal Blautia Is Associated with Reduced Death from Graft-versus-Host Disease. Biol Blood Marrow Transplant. 2015;21(8):1373-1383.

47. Weber D, Oefner PJ, Hiergeist A, Koestler J, Gessner A, Weber M, et al. Low urinary indoxyl sulfate levels early after transplantation reflect a disrupted microbiome and are associated with poor outcome. Blood. 2015;126(14):1723-1728.

48. Gerbitz A, Schultz M, Wilke A, Linde HJ, Scholmerich J, Andreesen R, et al. Probiotic effects on experimental graft-versus-host disease: let them eat yogurt. Blood. 2004;103(11):4365-7.

49. Shono Y, Docampo MD, Peled JU, Perobelli SM, Velardi E, Tsai JJ, et al. Increased GVHD-related mortality with broad-spectrum antibiotic use after allogeneic hematopoietic stem cell transplantation in human patients and mice. Sci Transl Med. 2016;8(339):339ra71.
50. Peled JU, Devlin SM, Staffas A, Lumish M, Khanin R, Littmann ER, et al. Intestinal Microbiota and Relapse After Hematopoietic-Cell Transplantation. J Clin Oncol. 2017;35(15):1650-1659.

51. Paulos CM, Wrzesinski C, Kaiser A, Hinrichs CS, Chieppa M, Cassard L, et al. Microbial translocation augments the function of adoptively transferred self/tumor-specific CD8+ T cells via TLR4 signaling. J Clin Invest. 2007;117(8):21972204.

52. Vetizou M, Pitt JM, Daillere R, Lepage P, Waldschmitt N, Flament C, et al. Anticancer immunotherapy by CTLA- 4 blockade relies on the gut microbiota. Science. 2015;350(6264):1079-1084.

53. Sivan A, Corrales L, Hubert N, Williams JB, Aquino-Michaels K, Earley ZM, et al. Commensal Bifidobacterium promotes antitumor immunity and facilitates anti-PD-L1 efficacy. Science. 2015;350(6264):1084-1089.

54. Hall CE, Koparde VN, Jameson-Lee M, Elnasseh AG, Scalora AF, Kobulnicky DJ, et al. Sequence homology between HLA-bound cytomegalovirus and human peptides: A potential trigger for alloreactivity. PloS one. 2017;12(8):e0178763.

55. Einsele H, Ehninger G, Hebart H, Weber P, Dette S, Link $\mathrm{H}$, et al. Incidence of local CMV infection and acute intestinal GVHD in marrow transplant recipients with severe diarrhoea. Bone Marrow Transplant. 1994;14(6):955-963.

56. Bhutani D, Dyson G, Manasa R, Deol A, Ratanatharathorn V, Ayash L, et al. Incidence, risk factors, and outcome of cytomegalovirus viremia and gastroenteritis in patients with gastrointestinal graft-versus-host disease. Biology of blood and marrow transplantation : journal of the American Society for Blood and Marrow Transplantation. 2015;21(1):159-164.

57. Pillet S, Pozzetto B, Roblin X. Cytomegalovirus and ulcerative colitis: Place of antiviral therapy. World J Gastroenterol. 2016;22(6):2030-2045.

58. Stevanovic S, van Bergen CA, van Luxemburg-Heijs SA, van der Zouwen B, Jordanova ES, Kruisselbrink AB, et al. HLA class II upregulation during viral infection leads to HLA-DP-directed graft-versus-host disease after CD4+ donor lymphocyte infusion. Blood. 2013;122(11):1963-1973.

59. Fiegl M, Gerbitz A, Gaeta A, Campe H, Jaeger G, Kolb HJ. Recovery from CMV esophagitis after allogeneic bone marrow transplantation using non-myeloablative conditioning: the role of immunosuppression. Journal of clinical virology : the official publication of the Pan American Society for Clinical Virology. 2005;34(3):219-223.

60. Wiesner M, Zentz C, Hammer MH, Cobbold M, Kern F, Kolb HJ, et al. Selection of CMV-specific CD8+ and CD4+ T cells by mini-EBV-transformed B cell lines. EurJ Immunol. 2005;35(7):2110-21.

61. Gamadia LE, Rentenaar RJ, van Lier RA, ten Berge IJ. Properties of CD4(+) T cells in human cytomegalovirus infection. Human immunology. 2004;65(5):486-492.

62. Elmaagacli AH, Steckel NK, Koldehoff M, Hegerfeldt Y, Trenschel R, Ditschkowski M, et al. Early human cytomeg- 
alovirus replication after transplantation is associated with a decreased relapse risk: evidence for a putative virus-versus-leukemia effect in acute myeloid leukemia patients. Blood. 2011;118(5):1402-1412.

63. Hill JA, Magaret AS, Hall-Sedlak R, Mikhaylova A, Huang ML, Sandmaier BM, et al. Outcomes of hematopoietic cell transplantation using donors or recipients with inherited chromosomally integrated HHV-6. Blood. 2017;130(8):1062-1069.

64. Hentrich M, Oruzio D, Jager G, Schlemmer M, Schleuning $M$, Schiel X, et al. Impact of human herpesvirus- 6 after haematopoietic stem cell transplantation. Br J Haematol. 2005;128(1):66-72.

65. Lieberman PM. Epigenetics and Genetics of Viral Latency. Cell Host Microbe. 2016;19(5):619-628.

66. Feuchtinger T, Lang P, Handgretinger R. Adenovirus infection after allogeneic stem cell transplantation. Leukemia \& lymphoma. 2007;48(2):244-255.

67. Liao YP, Jiang JL, Zou WY, Xu DR, Li J. Prophylactic antiviral therapy in allogeneic hematopoietic stem cell transplantation in hepatitis B virus patients. World journal of gastroenterology : WJG. 2015;21(14):4284-4292.

68. Tomblyn M, Chen M, Kukreja M, Aljurf MD, Al Mohareb F, Bolwell BJ, et al. No increased mortality from donor or recipient hepatitis B- and/or hepatitis C-positive serostatus after related-donor allogeneic hematopoietic cell transplantation. Transpl Infect Dis. 2012;14(5):468-478.

69. Ramos CA, Saliba RM, de Padua L, Khorshid O, Shpall EJ, Giralt S, et al. Impact of hepatitis $\mathrm{C}$ virus seropositivity on survival after allogeneic hematopoietic stem cell transplantation for hematologic malignancies. Haematologica. 2009;94(2):249-257.

70. Versluis J, Pas SD, Agteresch HJ, de Man RA, Maaskant J, Schipper ME, et al. Hepatitis E virus: an underestimated opportunistic pathogen in recipients of allogeneic hematopoietic stem cell transplantation. Blood. 2013;122(6):1079-1086.

71. Moosmann A, Bigalke I, Tischer J, Schirrmann L, Kasten J, Tippmer S, et al. Effective and long-term control of EBV PTLD after transfer of peptide-selected T cells. Blood. 2010;115(14):2960-2970.

72. Rooney CM, Smith CA, Ng CYC, Loftin SK, Li CL, Krance RA, et al. Use of gene-modified virus-specific T lymphocytes to control Epstein-Barr-virus-related lymphoproliferation. Lancet. 1995;345:9-13.

73. Feucht J, Opherk K, Lang P, Kayser S, Hartl L, Bethge W, et al. Adoptive T-cell therapy with hexon-specific Th1 cells as a treatment of refractory adenovirus infection after HSCT. Blood. 2015;125(12):1986-1994.

74. Hromas R, Cornetta K, Srour E, Blanke C, Broun ER. Donor leukocyte infusion as therapy of life-threatening adenoviral infections after T-cell-depleted bone marrow transplantation. Blood. 1994;84(5):1689-1690.
75. Versluys AB, Rossen JW, van Ewijk B, Schuurman R, Bierings MB, Boelens JJ. Strong association between respiratory viral infection early after hematopoietic stem cell transplantation and the development of life-threatening acute and chronic alloimmune lung syndromes. Biol Blood Marrow Transplant. 2010;16(6):782-791.

76. Legoff J, Resche-Rigon M, Bouquet J, Robin M, Naccache SN, Mercier-Delarue S, et al. The eukaryotic gut virome in hematopoietic stem cell transplantation: new clues in enteric graft-versus-host disease. Nat Med. 2017;23(9):1080-1085.

77. Pfeiffer JK, Virgin HW. Viral immunity. Transkingdom control of viral infection and immunity in the mammalian intestine. Science. 2016;351(6270).

78. Miura T, Sano D, Suenaga A, Yoshimura T, Fuzawa M, Nakagomi T, et al. Histo-blood group antigen-like substances of human enteric bacteria as specific adsorbents for human noroviruses. Journal of virology. 2013;87(17):9441-9451.

79. Ott SJ, Waetzig GH, Rehman A, Moltzau-Anderson J, Bharti R, Grasis JA, Cassidy L, Tholey A, Fickenscher H, Seegert D, Rosenstiel P, Schreiber S. Efficacy of sterile fecal filtrate transfer for treating patients with Clostridium difficile infection. Gastroenterology. 2017;152(4):799-811

80. Ye CJ, Feng T, Kwon HK, Raj T, Wilson MT, Asinovski $\mathrm{N}$, et al. Intersection of population variation and autoimmunity genetics in human $\mathrm{T}$ cell activation. Science. 2014;345(6202):1254665.

81. Gooley TA, Chien JW, Pergam SA, Hingorani S, Sorror $\mathrm{ML}$, Boeckh $\mathrm{M}$, et al. Reduced mortality after allogeneic hematopoietic-cell transplantation. $N$ Engl J Med. 2010;363(22):2091-2101.

82. Zeiser R, Blazar BR. Acute Graft-versus-Host Disease Biologic Process, Prevention, and Therapy. N Engl J Med. 2017;377(22):2167-2179.

83. Fleischhauer K, Shaw BE. HLA-DP in unrelated hematopoietic cell transplantation revisited: challenges and opportunities. Blood. 2017;130(9):1089-1096. 


\title{
I Инфекция и реакция «трансплантат против хозяина»
}

\author{
Ханс-Иохем Кольб ${ }^{1}$, Даниэла Вебер ${ }^{2}$, Белинда Пинто-Симоэс ${ }^{3}$, Эрнст Холлер ${ }^{2}$ \\ ${ }^{1}$ Кольб Консалтинг Мюнхен, Германия \\ ${ }^{2}$ Департамент гематологии и онкологии, клиника внутренних болезней III университетского медицинского центра, \\ Регенсбург, Германия \\ ${ }^{3}$ Школа медицины Рибейрао-Прето, Университет Сан-Пауло, Бразилия
}

\section{Резюме}

Роль инфекций при аллогенной трансплантации стволовых клеток (алло-ТГСК) и реакции «трансплантат против хозяина» (РТПХ) заново приобрела интерес ввиду нескольких разработок последних лет. Иммунодефицит различной степени возникает как следствие иммунной супрессии до тех пор, пока не сформируется донорская иммунная система; РТПХ и иммуносупрессивная терапия для профилактики и лечения РТПХ могут вызвать задержку ее восстановления. Эта ситуация способствует инфицированию различными микроорганизмами. Некоторые усовершенствования в профилактике и лечении инфекций, а также снижение интенсивности режимов кондиционирования и улучшение профилактики РТПХ привели к снижению токсичности лечения и смертности, связанной с трансплантацией.

Совершенствование терапии антибиотиками бактериальных, а также вирусных и грибковых инфекций внесло свой вклад в развитие этого успеха. Однако инфекции с РТПХ и без нее остаются основным препятствием для алло-ТГСК и иммунотерапии. Новые диагностические средства для исследования цитокинов, выделяющихся в период кондиционирования, состав микробиоты кишечника и ее изменения после ТГСК, а также врожденный иммунитет слизистой кишечника привнесли новый взгляд на патофизиологию РТПХ. Желудочно-кишечный тракт (ЖКТ) является первичным органом активации Т-лимфоцитов при острой РТПХ, и встречаемость РТПХ ассоциирована с меньшим разнообразием микроорганизмов в ЖКТ. Наличие определенных видов анаэробных бактерий ассоциируется со сниженным риском РТПХ и рецидивов лейкоза. Недавние исследования показали, что колонизации ЖКТ некоторыми штаммами Blautia ассоциированы с меньшим риском РТПХ, а ряд линий Limus (Eubacteriaceae) связан со снижением частоты рецидивов. Этот антилейкозный механизм не вполне выяснен. Частой находкой здесь является продукция короткоцепочечных жирных кислот. Таким образом, вопрос о полной или избирательной деконтаминации ЖКТ пока не разрешен. Улучшение выживаемости было описано при деконтаминации рифамиксином, что связывают с выживанием анаэробов и повышенной продукцией индоксилсульфата. Предпринимались попытки лечения РТПХ кишечника путем переноса стула здоровых лиц, что приносило некоторый успех. Это может не только оказывать положительный эффект на бактериальную флору, но и на их взаимодействие с фагами и другими микроорганизмами.

Нынешние исследования вирома показали присутствие пикорнавируса, ассоциированного с РТПХ.

Слизистая ЖКТ является важной частью иммунной системы, и имеется тонкое равновесие между флорой как таковой и иммунологическим надзором со стороны иммунной системы организма-хозяина. Имеется достаточно доказательств того, что иммунная система слизистых оболочек играет важнейшую роль в развитии иммунного ответа у больных против пищевых антигенов и микробных антигенов, тем самым различая иммунные реакции и иммунную толерантность.

Вирусные инфекции, как известно, прокладывают путь для последующих грибковых и бактериальных инфекций, но сложные взаимодействия между вирусами, бактериями грибками, нематодами и слизистой оболочкой могут осложнять общую картину. До сих пор во многом не ясно, насколько важен взаимный контроль различных царств микробиоты и он может быть связан с малоизученной ролью бактериофагов которые могут модулировать микробную колонизацию. Эти взаимодействия могут осложняться применением в клинике абсорбируемых и неабсорбируемых антибиотиков, антивирусных и других препаратов.

Есть и некоторые перспективные способы предотвращения и лечения РТПХ. Так, можно выбирать доноров в соответствии с их иммунным репертуаром и генетическим фоном для активации Т-клеток. Возможно, этот подход может сочетаться с антилейкемическим эффектом, основанным на антимикробной активности и тканевой совместимости по HLA (класс II DP-гены). В общем, иммунная активация может быть важной в аспекте ее индукции имеющейся микробиотой, и она определяется генетическими факторами донора и реципиента.

\section{Ключевые слова}

Аллогенная трансплантация гемопоэтических клеток, реакция «трансплантат против хозяина», инфекции, профилактика, микробиота желудочно-кишечного тракта, генетические факторы, антиинфекционная терапия. 